University of Cambridge, Department of Biochemistry, Tennis Court Road, The Downing Site, Cambridge CB2 1QW, UK

\section{Erwinia carotovora DsbA mutants: evidence for a periplasmic-stress signal transduction system affecting transcription of genes encoding secreted proteins}

\author{
Lois V. Vincent-Sealy, † Joanna D. Thomas, $\neq$ Paul Commander \\ and George P. C. Salmond
}

Author for correspondence: George P. C. Salmond. Tel: +44 1223 333650. Fax: +44 1223333345.
e-mail: gpcs@mole.bio.cam.ac.uk

The dsbA genes, which encode major periplasmic disulfide-bond-forming proteins, were isolated from Erwinia carotovora subsp. carotovora (Ecc) and Erwinia carotovora subsp. atroseptica (Eca), and the dsbC gene, encoding another periplasmic disulfide oxidoreductase was isolated from Ecc. All three genes were sequenced and mutants deficient in these genes were created by marker exchange mutagenesis. The Ecc mutants were severely affected in activity and secretion of pectate lyase, probably due to the absence of functional PelC, which is predicted to require disulfide bond formation to achieve its correct conformation prior to secretion across the outer membrane. Similarly, endopolygalacturonase, also predicted to possess disulfide bonds, displayed reduced activity. The major Ecc cellulase (CelV) does not contain cysteine residues and was still secreted in dsbA-deficient strains. This observation demonstrated unequivocally that the localization and activity of the individual components of the Out apparatus are independent of disulfide bond formation. Surprisingly, cellulase activity was shown to be increased $\sim$ two- to threefold in the DsbA mutant. This phenomenon resulted from transcriptional up-regulation of ce/ $V$ gene expression. In contrast, transcription of both pe/C and peh were down-regulated in dsbA-deficient strains when compared to the wild-type. Protease (Prt) activity and secretion were unaffected in the Ecc dsbA mutant. Prt activity was considerably reduced in the double dsbA dsbC mutant. However Prt was secreted normally in this strain. The Eca dsbA mutant was found to be non-motile, suggesting that disulfide bond formation is essential for motility in this strain. All of the dsb mutants showed reduced tissue maceration in planta. These results suggest that a feedback regulation system operates in Ecc. In this system, defects in periplasmic disulfide bond formation act as a signal which is relayed to the transcription machinery regulating gene expression in diverse ways.

Keywords: Erwinia carotovora, general secretory pathway, secretion, exoenzymes, motility

\footnotetext{
† Present address: Department of Life Sciences, Faculty of Agriculture and Natural Science, University of West Indies, St Augustine, Trinidad, West Indies. ¥Present address: Biological Sciences, University of Warwick, Coventry CV4 7AL, UK.

Abbreviations: BGal, $\beta$-galactosidase; Cel, cellulase(s); Eca, Erwinia carotovora subsp. atroseptica; Ecc, Erwinia carotovora subsp. carotovora; Echr, Erwinia chrysanthemi; OHHL, N-(3-oxohexanoyl)-L-homoserine lactone; Peh, endopolygalacturonase; Pel, pectate lyase(s); Prt, protease(s).

The GenBank accession numbers for the Ecc dsbA, Eca dsbA and Ecc dsbC sequences reported in this paper are AF146615, AF146613 and AF146614, respectively.
} 


\section{INTRODUCTION}

Erwinia carotowora subsp. carotovora (Ecc) and Erwinia caroton'ora subsp. atroseptica (Eca) are Gram-negative phytopathogens which cause soft rotting of vegetable crops via a battery of exoenzymes, including cellulases (Cel), pectate lyases (Pel), endopolygalacturonase (Peh), pectin lyase and pectin methylesterase. Several of these exoenzymes are secreted via the sec-dependent type II or general secretory pathway (GSP) in a two-step manner. The first step is analogous to sec-dependent export in Escherichia coli (Pugsley, 1993), and in the second step proteins are secreted from the periplasm to the extracellular milieu by a complex of at least 13 proteins comprising the Ecc Out apparatus (Reeves et al., 1993; unpublished data). This secretion pathway is highly conserved among (iram-negative bacteria and homologues of the Out proteins are involved in targeting virulence determinants in other plant and animal pathogens (Pugsley, 1993; Salmond \& Reeves, 1993; Salmond 1994; Wharam et al., 1995).

Several Enuinia spp. produce protease (Prt) activity. The role of Prt in the virulence of Eruinia spp. is not clear (Andro et al., 1984). The normal secretion of Prt in Ecc Out ${ }^{-}$mutants (Murata et al., 1990; Reeves et al., 1993) indicates that these enzymes are not secreted via the type Il system. Evidence from work carried out in the closely related phytopathogen Eruinia chrysanthemi (Echr) strongly suggests that the type I secretory pathway is used instead (Wandersman \& Létoffé, 1993). Proteins that go through this pathway do so in a sec-independent, one-step manner which does not appear to involve a free periplasmic intermediate (Pugsley, 1993).

Many of the proteins targeted via the type II pathway require the formation of disulfide bonds in the periplasm for activity (Peck \& Taylor, 1992; Yu et al., 1992; 1993; Bortolli-Crerman et al., 1994; Shevchik et al., 1994, 1995). Achieving a particular conformation might be necessary for periplasmic intermediates to present a signal that can be recognized by the secretion apparatus. However, attempts to identify such a signal have been inconclusive (Wong \& Buckley, 1991; Py et al., 1993; McVay \& Hamood, 1995; Lu \& Lory, 1996; Sauvonnet \& Pugsley, 1996; Palomaki \& Saarilahti, 1997).

In E. coli periplasmic disulfide bond formation is achieved by the Dsb system comprising a family of disulfide oxidoreductases which possess the -C-X-X-Cmotif characteristic of thioredoxin and protein disulfide-isomerase (Missiakas \& Raina, 1997). The periplasmic DsbA appears to be the most important, its role being to transfer disulfide bonds to folding proteins in the periplasm - a process that results in their oxidation (Bardwell, 1994). DsbC acts as a periplasmic isomerase involved in disulfide rearrangement, especially in proteins with several disulfide bonds (Rietsch et al., 1996).

Homologous members of the Dsb family have been found in other Gram-negative bacteria, and several are important in periplasmic folding of virulence factors prior to secretion (Peek \& Taylor, 1992; Tomb, 1992; Yu et al., 1992, 1993; Yamanaka et al., 1994; Shevchik et al., 1994, 1995; Ishihara et al., 1995; Okamoto et al., 1995; Watari et al., 1995; Foreman et al., 1995; Abe \& Nakazawa, 1996; Rodriguez-Pena et al., 1997). Absence of the Dsb system generally results in inactive proteins, a lack of secretion competence and retention of the unor misfolded proteins in the periplasm, where they are usually degraded by resident Prt (Peek \& Taylor, 1992; Yu et al., 1992, 1993; Bortolli-German et al., 1994; Shevchik et al., 1994, 1995). However, the question as to why DsbA mutations reduce secretion via the type II pathway remains open.

Pullulanase (PulA) of Klebsiella oxytoca contains at least one DsbA-catalysed intramolecular disulfide bond. The absence of DsbA diminishes the rate of pullulanase secretion but the disulfide bonds in this enzyme are not needed for its secretion (Pugsley, 1992; Sauvonnet \& Pugsley, 1998). By contrast, the major cellulase, CelZ, of Echr requires disulfide bond formation and hence DsbA for both enzyme stability and secretion (BortolliGerman et al., 1994). The role of DsbA in the secretion of lipase and aerolysin by Aeromonas spp. has not been studied, but these proteins contain disulfide bonds whose removal has no effect on their secretion (Hardie et al., 1995; Brumlik et al., 1997). Thus, three different phenomena occur in related secretion systems.

It is presumed that these Dsb effects are not due to a direct effect on the assembly or function of the secretion apparatus (Pugsley, 1992; Peek \& Taylor, 1992; Yu et al., 1992, 1993; Bortolli-German et al., 1994; Shevchik et al., 1994, 1995; Sauvonnet \& Pugsley, 1998) despite most of the components comprising the secretion apparatus being inner-membrane proteins protruding into the periplasm (Reeves et al., 1994; Bleves et al., 1996; Thomas et al., 1997). However, the potential for these periplasmic domains to form disulfide bonds is equivocal. Pugsley (1992) stated that although several of the K. oxytoca type II apparatus (Pul) proteins have one or more cysteine residues, almost all of these are in putative transmembrane regions. We noted that the Ecc OutK and OutN proteins (both of which have large periplasmic domains; Reeves et al., 1994) each contain two cysteines (residues 103 and 209 in OutK, and residues 145 and 177 in $\mathrm{OutN}$ ) with the potential to form an intramolecular disulfide bond. Moreover, an alignment of the OutK and OutN homologues showed that these residues are highly conserved.

We decided to investigate the role of periplasmic disulfide bond formation in Ecc. This bacterium produces enzymes which are secreted via two different pathways - type I (Prt) and type II (pectinases and Cel) - and it was predicted that, due to the absence of a periplasmic intermediate, the Ecc Prt isozymes should achieve a Dsb-independent secretion-competent state. Most of the type-11-targeted proteins investigated have disulfide bonds (Hardy et al., 1988; Pugsley, 1992; Peek \& Taylor, 1992; Bortolli-German et al., 1994; Shevchik et al., 1994, 1995) and, hence, present difficulties when used to assess the effect of disulfide bond formation on the secretion apparatus. Not all the proteins which traverse the Ecc type II pathway contain cysteine 
residues; unlike Echr CelZ (Guiseppi et al., 1988), the major Cel isozyme of Ecc, CelV, does not contain cysteines (Cooper \& Salmond, 1993). However, Peh, and the major Pel isozyme (PelC) of Ecc each contain four cysteines with potential to form two intramolecular disulfide bonds (Hinton et al., 1989, 1990). Therefore, we were in the position to test unequivocally if disulfide bond formation has any effect on the type II system. In addition, we investigated the role of disulfide bond formation in virulence in Ecc and Eca.

\section{METHODS}

Bacterial strains, DNA constructs, bacteriophages and media. Bacterial strains, DNA constructs and bacteriophages used are listed in Table 1 . Bacterial strains were routinely grown with shaking at 250 r.p.m. in Luria broth (LB), or on Luria broth agar (LBA) or nutrient broth agar (NBA), containing appropriate antibiotics where necessary, at 37,30 and $27^{\circ} \mathrm{C}$ for E. coli, Ecc and Eca, respectively. Media supplements were added at the following final concentrations: ampicillin (Ap), kanamycin $(\mathrm{Kn})$, spectinomycin $(\mathrm{Sp})$ and chloramphenicol $(\mathrm{Cm}), 50 \mu \mathrm{g} \mathrm{ml}^{-1}$; tetracycline $(\mathrm{Tc}) 10 \mu \mathrm{g} \mathrm{ml}^{-1}$; streptomycin (Str), $50 \mu \mathrm{g} \mathrm{ml}^{-1}$; IPTG, $30 \mu \mathrm{g} \mathrm{ml}^{-1}$; 5-bromo-4-chloro-3indolyl $\beta$-D-galactoside, $30 \mu \mathrm{g} \mathrm{ml}^{-1} ; 5$-bromo-4-chloro-3indolyl $\beta$-D-glucuronide, $50 \mu \mathrm{g} \mathrm{ml}^{-1}$. All general recombinant DNA techniques were performed as described by Sambrook et al. (1989). Plasmid DNA was introduced into E. coli, Ecc and Eca by electroporation (Solioz \& Bienz, 1990).

DNA sequence analysis. Nucleotide sequence analysis was performed by the method of Sanger et al. (1977) using the Sequenase (USB) DNA sequencing kit. The sequences were analysed using the Wisconsin Genetics Computer Group, version 8 (1994) computer program (GCG) and BLAST.

Cell fractionation. Ecc strains were grown in $5 \mathrm{ml} \mathrm{Pel} \mathrm{minimal}$ broth (PMB; Reeves et al., 1993) at $30^{\circ} \mathrm{C}$ to stationary phase $\left(\mathrm{OD}_{600} 4 \cdot 0\right)$. An aliquot $(0.5 \mathrm{ml})$ of $0.5 \mathrm{M}$ Tris $/ \mathrm{HCl}(\mathrm{pH} 7.8)$ was added and after incubation for $10 \mathrm{~min}$ at room temperature the cultures were centrifuged (Labor $50-\mathrm{M}, 3630 \mathrm{~g}$, $5 \mathrm{~min}, 4^{\circ} \mathrm{C}$ ) and the supernatant harvested (extracellular fraction). The pellet was washed once in PMB, resuspended in $800 \mathrm{ml}$ sucrose solution $(30 \mathrm{mM}$ Tris, $40 \%$ sucrose, $2 \mathrm{mM}$ EDTA) after recentrifugation, incubated at $30^{\circ} \mathrm{C}$ for $10 \mathrm{~min}$ and then centrifuged again. This supernatant was discarded and the pellet resuspended in $1 \mathrm{ml}$ ice-cold distilled water, incubated on ice for $10 \mathrm{~min}$ and then centrifuged as before. This resulting supernatant was retained as the periplasmic fraction. The pellet was resuspended in $5 \mathrm{ml} 50 \mathrm{mM}$ Tris (pH 7.8) and sonicated (MSE sonicator) on ice for $3 \times 30 \mathrm{~s}$ at an amplitude of 6 with a 0.7 inch probe at $4{ }^{\circ} \mathrm{C}$, with $30 \mathrm{~s}$ rest between each sonication, to produce the cytoplasmic fraction. Cell debris was removed by centrifugation as before. Fractions were stored at $-20^{\circ} \mathrm{C}$. The fidelity of cell fractionation was assessed by assaying for the marker enzymes $\beta$-lactamase (periplasmic) and $\beta$-galactosidase (BGal; cytoplasmic) as described previously (Reeves et al., 1993).

Exoenzyme activity. Exoenzyme activity was assessed using indicator media (Reeves et al., 1993) and quantified using spectrophotometric assays of cellular fractions (Hinton \& Salmond, 1987; Reeves et al., 1993). BGal activity of strains carrying transcriptional lac $Z$ fusions was assessed as follows. Overnight cultures were diluted in $50 \mathrm{ml} \mathrm{PMB}$ to an initial $\mathrm{OD}_{600}$ of $\sim 0.06$. Three replicas were grown at $30^{\circ} \mathrm{C}$ and 250 r.p.m. to stationary phase $(\sim 10 \mathrm{~h})$. Samples were removed, sonicated and assayed in triplicate as described previously
(Reeves et al., 1993). Where necessary, $\mathrm{OD}_{420}$ values were corrected for light scattering by cell debris using the formula $\mathrm{OD}_{420}-\left(1.75 \times \mathrm{OD}_{550}\right)$ (Miller, 1992). Protein concentrations were determined using the Bio-Rad Protein Assay.

Cosmid complementation of $E$. coli strain JCB571. Three cosmid libraries were used to transduce the non-motile $E$. coli strain JCB571 following standard procedures (Sambrook et al., 1989). pSF6- and pHC79-based cosmid libraries of Ecc SCRI193 packaged into phage $\lambda\left(\mathrm{Sp}^{\mathrm{R}}\right.$ and $\mathrm{Ap}^{\mathrm{R}}$ selection, respectively; $P$. Reeves, unpublished) were used to isolate the Ecc $d s b A$ and $d s b C$ genes, respectively. A pSF6-based cosmid library of Eca SCRI1043 packaged into phage $\lambda\left(\mathrm{Sp}^{R}\right.$ selection; $\mathrm{S}$. Bentley, unpublished) was used to isolate the Eca $d s b A$ gene. Transductants were screened for restoration of motility as described below.

Motility assay. E. coli and Eca colonies were screened for complementation by stabbing into tryptone swarm agar (TSA) plates (Wolfe \& Berg, 1989) and incubating at $37^{\circ} \mathrm{C}$ for $16 \mathrm{~h}$, or at $27^{\circ} \mathrm{C}$ for $48 \mathrm{~h}$, respectively. The motility of Eca mutants was assessed via halo diameter after spotting $5 \mu$ l aliquots of cultures, grown overnight in PMB at $27^{\circ} \mathrm{C}$, onto TSA plates and incubating at $27^{\circ} \mathrm{C}$ for $48 \mathrm{~h}$.

In planta potato tuber virulence assays. Virulence assays were done essentially as described previously (Walker et al., 1994). Potatoes of the cultivars Colmo Tops, Pentland Javelin or Maris Piper were inoculated with $10^{3}$ bacterial cells and incubated for $96 \mathrm{~h}$ at $25^{\circ} \mathrm{C}$. Macerated tissue was removed and weighed every $24 \mathrm{~h}$. Results were expressed as the mean value of six replicas of each strain for each time point. Each assay was carried out at least twice and using at least two different cultivars.

Immunoblot analysis. SDS-PAGE and immunoblot analysis were performed as described by Silhavy et al. (1984) and Sambrook et al. (1989), respectively. Proteins were transferred to a nitrocellulose filter (Hybond-C; Amersham) and incubated with primary antibody followed by a secondary anti-rabbit horseradish peroxidase antibody (Amersham). 4Chloro-1-naphthol (Sigma) was used for signal detection.

Marker exchange mutagenesis. To generate pCM3, a gusA/ $\mathrm{Cm}^{\mathrm{R}}$ cassette (from pUIDC1; Bardonnet \& Blanco, 1992) was excised on an EcoRI/HindIII fragment, end-filled and cloned into the Ecc $d s b A$ gene (carried in $\mathrm{pBH}$ ) at the $X b a$ I site (which had also been end-filled). The $d s b A-g u s A$ allele was excised from pCM3 on a ClaI/Sall fragment and end-filled, then cloned into the SmaI site of the suicide vector pKNG101 (Kaniga et al., 1991), generating pACS. The construction of marker exchange plasmids for the Ecc $d s b C$ and Eca $d s b A$ genes was carried out in a similar manner. A $g u s A / \mathrm{Kn}^{\mathrm{k}}$ cassette (from pUIDK1; Bardonnet \& Blanco, 1992) was excised on a HindIII/Hpal fragment and end-filled. This fragment was inserted at the $\mathrm{HpaI}$ site of the Ecc $d s b \mathrm{C}$ gene carried in $\mathrm{pHH}$, and at the $\mathrm{Ncol}$ (end-filled) site of the Eca $d s b A$ gene carried in $\mathrm{pBAT}$, to generate $\mathrm{pCAK}$ and $\mathrm{pAM}$, respectively. A HindIII fragment from pCAK and an EcoRI/ HindIIl fragment from pAM were cloned separately into the Smal site of pKNG101 to generate the marker exchange constructs $\mathrm{pCSK}$ and $\mathrm{pAMK}$, respectively.

To generate $\mathrm{pVicL}$, a promoterless lacZ cassette (from $\mathrm{pSH} 24$; S. Harris, unpublished) was excised on a Bam HI/HindIII fragment, end-filled and cloned into the EcoRV site of celV (carried on pVic626; Cooper \& Salmond, 1993). The mutated gene was excised on a SphI/EcoRI fragment, end-filled and cloned into the SmaI site of pKNG101, generating pVicLK. lac $Z$ transcriptional fusions were created in the Ecc pelC and 
Table 1. Strains, constructs and phage used in this study

\begin{tabular}{|c|c|c|c|}
\hline Strain/construct/phage & & Relevant characteristics & Source/reference \\
\hline \multicolumn{4}{|l|}{ Strains } \\
\hline \multirow[t]{4}{*}{ Escherichia coli } & CC118 (ipir) & $\begin{array}{l}\text { (ara-leu) araD lacX74 galE galK phoA20 thi-1 } \\
\text { rpsE rpoB argE(AM) recA1, lysogenized with }\end{array}$ & Herrero et al. (1990) \\
\hline & JCB570 & $\begin{array}{l}\text { ipir phage } \\
\text { phoR zih12::Tn10 }\end{array}$ & Bardwell et al. (1991) \\
\hline & JCB571 & JCB $570, d s b A:: k a n 1$ & Bardwell et al. (1991) \\
\hline & $\mathrm{HH} 26$ & $\mathrm{pNJ} 5000, \mathrm{Tc}^{\mathrm{K}}$ & Grinter (1983) \\
\hline \multirow{2}{*}{$\begin{array}{l}\text { Erwinia carotowora subsp. } \\
\text { atroseptica (Eca) }\end{array}$} & SCRI1043 & Wild-type, motile & Mulholland et al. (1993) \\
\hline & LS4AA & SCRI1043, dsbA::gusA $/ \mathrm{Kn}^{\mathrm{H}}$, non-motile & This study \\
\hline \multirow{11}{*}{$\begin{array}{l}\text { Eruinia carotowora subsp. } \\
\text { carotowora (Ecc) }\end{array}$} & SCRI193 & Wild-type, non-motile & Forbes \& Perembelon (1985) \\
\hline & $\mathrm{MH} 1000$ & SCRI193, $\mathrm{Lac}^{-}$ & Harris et al. (1998) \\
\hline & LS1A & SCRI193, dsbA::gusA $/ \mathrm{Cm}^{\mathrm{H}}$ & This study \\
\hline & LS2C & SCRI193, dsbC::gusA $/ \mathrm{Kn}^{\mathrm{k}}$ & This study \\
\hline & LS3AC & $\begin{array}{l}\text { SCRI193, dsbA::gusA/ } \mathrm{Cm}^{\mathrm{R}} \\
d s b C:: g u s A / \mathrm{Kn}^{\mathrm{K}}\end{array}$ & This study \\
\hline & LS5V & MH1000, celV::lacZ & This study \\
\hline & LS6VA & MH1000, celV::lacZ $d s b A:: g u s A / \mathrm{Cm}^{\mathrm{H}}$ & This study \\
\hline & LSTP & MH1000, pelC::lacZ & This study \\
\hline & LS8PA & $\mathrm{MH} 1000$, pelC:: lacZ dsbA::gusA/Cm ${ }^{\mathrm{K}}$ & This study \\
\hline & LS9H & MH1000, peb: : lacZ & This study \\
\hline & $\mathrm{LS} 10 \mathrm{HA}$ & MH1000, peh::lacZ dsbA::gusA/ $\mathrm{Cm}^{\mathrm{K}}$ & This study \\
\hline \multirow[t]{37}{*}{ Plasmids/cosmids } & pBR322 & Cloning vector, $A p^{R} T c^{R}$ & Bolivar et al. (1977) \\
\hline & pUC19 & Cloning vector, $\mathrm{Ap}^{\mathrm{R}}$ & Yanisch-Perron et al. (1985) \\
\hline & pBluescript II & Cloning vector, $\mathrm{Ap}^{\mathrm{B}}$ & Atling-Mees \& Short (1989) \\
\hline & pUIDC1 & Promotorless gusA $/ \mathrm{Cm}^{\mathrm{R}}$ cassette, $\mathrm{Ap}^{\mathrm{K}}$ & Bardonnet \& Blanco (1992) \\
\hline & pUIDK 1 & Promotorless gusA $/ \mathrm{Kn}^{\mathrm{K}}$ cassette, $\mathrm{Ap}^{\mathrm{K}}$ & Bardonnet \& Blanco (1992) \\
\hline & $\mathrm{pSH} 24$ & Promotorless lac $Z$ gene, $\mathrm{Ap}^{\mathrm{K}}$ & $\begin{array}{l}\text { S. Harris, University of } \\
\text { Cambridge, UK }\end{array}$ \\
\hline & pKNG101 & Suicide vector, $\mathrm{Str}^{\mathrm{R}} \mathrm{SacB}^{+}$ & Kaniga et al. (1991) \\
\hline & pSF6 & Cosmid vector, $\mathrm{Mob}^{+} \mathrm{Sp}^{\mathrm{R}} \mathrm{Str}^{\mathrm{R}}$ & Selvaraj et al. (1984) \\
\hline & $\mathrm{pHC} 79$ & Cosmid vector, pBR322::cos, $\mathrm{Ap}^{\mathrm{K}} \mathrm{Tc}^{\mathrm{H}}$ & Hohn \& Collins $(1980)$ \\
\hline & pNJ5000 & IncP, $\mathrm{Tc}^{\mathrm{R}} \mathrm{Tra}^{+}$ & Grinter (1983) \\
\hline & cMS 1 & 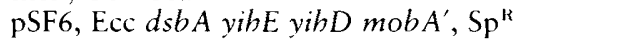 & This study \\
\hline & cM2 & $\mathrm{pHC} 79, \mathrm{Ecc} d s b \mathrm{C}, \mathrm{Ap}^{\mathrm{K}}$ & This study \\
\hline & cAT1 & pSF6, Eca $d s b A, \mathrm{Sp}^{\mathrm{K}}$ & This study \\
\hline & pMSIE & $\mathrm{pBR} 322$, Ecc $d s b A$ yihE yihD $m o b A^{\prime}, \mathrm{Ap}^{\mathrm{R}}$ & This study \\
\hline & pES & pBR322, EcoRI/Sall pMS1E fragment, Ap ${ }^{\mathrm{R}}$ & This study \\
\hline & pSE & pBR322, Sall/EcoRI pMS1E fragment, Ap ${ }^{\mathrm{K}}$ & This study \\
\hline & $\mathrm{pBE}$ & pBR322, BamHI/EcoRI pMS1E fragment, $\mathrm{Ap}^{\mathrm{k}}$ & This study \\
\hline & $\mathrm{pBH}$ & $\mathrm{pBR} 322, \mathrm{Ecc} d s b A^{\prime} y i b E, \mathrm{Ap}^{\mathrm{R}}$ & This study \\
\hline & $\mathrm{pHIN}$ & 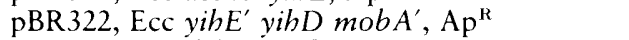 & This study \\
\hline & $\mathrm{pHH}$ & $\mathrm{pBR} 322, \mathrm{Ecc} d s b C, \mathrm{Ap}^{\mathrm{R}}$ & This study \\
\hline & pBAT & pBR322, Eca $d s b A$ yibE $E^{\prime}, \operatorname{Ap}^{\mathrm{R}}$ & This study \\
\hline & $\mathrm{pCM} 3$ & $\mathrm{pBH}, \mathrm{Ecc} d s b A:: g u s A / \mathrm{Cm}^{\mathrm{R}}, \mathrm{Ap}^{\mathrm{K}}$ & This study \\
\hline & pACS & pKNG101, Ecc dsbA::gusA/Cm ${ }^{\mathrm{R}}, \mathrm{Str}^{\mathrm{K}}$ & This study \\
\hline & pCAK & $\mathrm{pHH}, \mathrm{Ecc} d s b C:: g u s A / \mathrm{Kn}^{\mathrm{R}}, \mathrm{Ap}^{\mathrm{R}}$ & This study \\
\hline & pCSK & pKNG101, Ecc ds bC::gusA/Kn ${ }^{\mathrm{K}}, \mathrm{Str}^{\mathrm{K}}$ & This study \\
\hline & pAM & pBAT, Eca $d s b A:: g u s A / \mathrm{Kn}^{\mathrm{R}}, \mathrm{Ap}^{\mathrm{R}}$ & This study \\
\hline & pAMK & pKNG101, Eca dsbA::gusA/Kn ${ }^{\mathrm{R}}, \mathrm{Str}^{\mathrm{R}}$ & This study \\
\hline & pVic626 & pBR322, Ecc celV, Ap ${ }^{\mathrm{R}}$ & Cooper \& Salmond (1993) \\
\hline & pVicL & pVic626, Ecc celV::lac $Z, A^{\mathrm{R}}$ & This study \\
\hline & pVicLK & pKNG101, Ecc celV::lacZ, Str ${ }^{\mathrm{R}}$ & This study \\
\hline & pJS6197 & pUC19, Ecc pelC, Ap ${ }^{\mathrm{R}}$ & Hinton et al. (1989) \\
\hline & pJSKL & pUC19, Ecc pelC::lacZ, Ap ${ }^{\mathrm{H}}$ & This study \\
\hline & PJSLK & pKNG101, Ecc pelC::lacZ, Str ${ }^{\mathrm{K}}$ & This study \\
\hline & $\mathrm{pE} 4$ & pUC8, Ecc peh, Ap ${ }^{\mathrm{K}}$ & Hinton et al. (1990) \\
\hline & pES4 & pUC19, Ecc peh, Ap ${ }^{K}$ & This study \\
\hline & pESL4 & pES4, Ecc peh::lacZ, Ap ${ }^{\mathrm{K}}$ & This study \\
\hline & pESLK & pKNG101, Ecc peh::lacZ, Str ${ }^{\mathrm{R}}$ & This study \\
\hline \multirow[t]{2}{*}{ Phage } & $\mathrm{M} 13 \mathrm{mp} 8$ & Sequencing coliphage vector & Messing \& Vieira (1982) \\
\hline & $\phi \mathrm{KP}$ & Ecc generalized transducing phage & Toth et al. (1993) \\
\hline
\end{tabular}



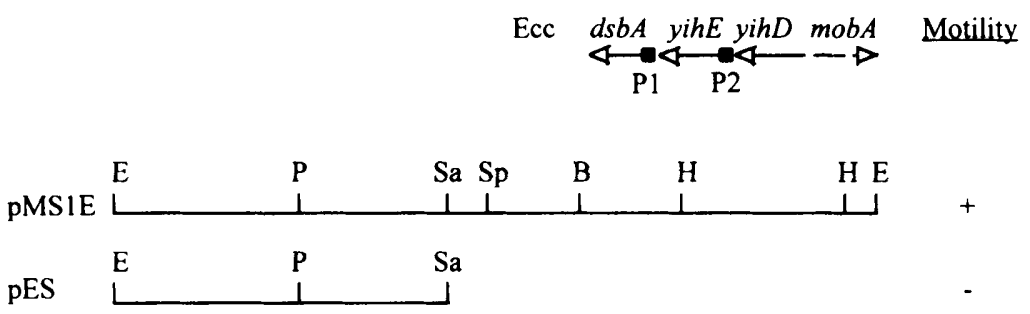

Fig. 1. Subcloning of the Ecc genomic DNA
fragment in pMSE1. Restriction map of the
$8 \mathrm{~kb}$ Ecc genomic DNA fragment in the
complementing clone pMSE1. Subclones
were assessed for restoration of wild-type
levels of motility to the non-motile $E$. coli
dsbA strain, JCB571. Nucleotide sequencing
of the genomic DNA inserts of pBH and
pHIN revealed the genetic organization
shown for this region. E, EcoRI; B, BamHI; $\mathrm{H}$,

peh genes in a similar manner. The same promoterless lacZ cassette was inserted into the Hpal site of pelC (carried on pJS6197; Hinton et al., 1989) and the SnaBI site of peh (carried on pES4, a derivative of pE4; Hinton et al., 1990), to generate pJSKL and pESL4, respectively. The mutated alleles were excised on a $\mathrm{Narl} / \mathrm{HindIII}$ fragment and a BamHI/EcoRI fragment, respectively, end-filled and cloned into the $S$ maI site of pKNG101 to generate pJSLK and pESLK, respectively. All genetic manipulations using the recombinant pKNG101 plasmids were carried out in the E. coli strain CC118 (ipir; Herrero et al., 1990).

Marker exchange mutagenesis was done essentially as described by Thomson et al. (1997). Strains that had undergone resolution of the integrated plasmid were selected in the absence of antibiotic (lacZ), or the presence of $\mathrm{Cm}$ (gusA) $\mathrm{Cm}^{\mathrm{R}}$ ) or $\mathrm{Kn}\left(\mathrm{gus} A / \mathrm{Kn}^{\mathrm{R}}\right)$ as appropriate. Southern blotting confirmed the genotype of putative mutants. The Ecc-specific transducing phage $\phi \mathrm{KP}$ was used to transduce chromosomal mutations into different Ecc genetic backgrounds, essentially as described previously (Toth et al., 1993).

\section{RESULTS AND DISCUSSION}

\section{Isolating dsb genes of Ecc SCRI193 and Ecc SCRI1043}

Cosmid complementation of JCB571 was used to isolate $d s b$ genes of Ecc SCRI193 and Eca SCRI1043. $\lambda$-based cosmid libraries of Ecc and Eca genomic DNA were used to transduce JCB571 and transductants were screened for restoration of motility on TSA plates, compared to the wild-type strain, JCB570 (data not shown). Two types of complementing clones were isolated from the Ecc SCRI193 libraries. The first type, represented by cMS1 and isolated from a pSF6-based library, allowed full restoration of motility at an incubation temperature of $37^{\circ} \mathrm{C}$, and was subsequently found to contain the Ecc $d s b A$ gene. The second type, represented by cM2 and isolated from a pHC79-based library, consistently provided full complementation at $30^{\circ} \mathrm{C}$ but only partial complementation at $37^{\circ} \mathrm{C}$, and was later found to contain the Ecc $d s b C$ gene. The lower temperature was used to increase the possibility of isolating $d s b C$ (Shevchik et al., 1994). The cosmid cAT1, carrying the
Eca $d s b A$ gene, was isolated similarly at $30^{\circ} \mathrm{C}$ using a pSF6-based cosmid library of Eca SCRI1043.

These cosmids carried $\sim 30 \mathrm{~kb}$ fragments of genomic DNA and were shown to display different enzyme restriction patterns (data not shown). Random cloning was used to subclone each cosmid into pBR322. JCB571 transformants were scored for restoration of motility on TSA plates (data not shown). In the case of cMS1, a subclone containing an $8 \mathrm{~kb}$ EcoRI fragment, pMS1E, was isolated. pMS1E was restriction-mapped and pBR322 subclones were tested for complementation of JCB571 as before (Fig. 1). The inserts of pBH $(1 \cdot 1 \mathrm{~kb}$ BamHI/HindIII Ecc fragment), $\mathrm{pHH}$ (1 kb HindIII Ecc fragment) and pBAT (1.1 kb BamHI Eca fragment) were derived from cMS1, cM2 and cAT1, respectively. Southern hybridization using $\mathrm{pBH}$ as probe DNA and $\mathrm{pHH}$ as template DNA revealed that these constructs contained different Ecc genomic DNA fragments (data not shown).

\section{DNA sequence analysis of the Ecc and Eca dsbA genes}

The genomic DNA inserts of $\mathrm{pBH}, \mathrm{pHH}$ and $\mathrm{pBAT}$ were sequenced. $\mathrm{pBH}$ contained an Ecc DNA insert of 1126 bp (GenBank accession no. AF146615) with a single ORF of 621 nucleotides, beginning at residue 264 and ending at residue 884 . This ORF encoded a predicted protein of 207 amino acids, with an $M_{\mathrm{r}}$ of $23 \mathrm{kDa}$, and exhibited $81 \%$ and $70 \%$ identity to the Echr and E. coli DsbA proteins, respectively.

pBAT had an Eca DNA insert of 1058 bp (GenBank accession no. AF146613) with a single ORF of 621 nucleotides, beginning at residue 155 and ending at residue 775 . This ORF encoded a predicted protein of 207 amino acids, with an $M_{r}$ of $23 \mathrm{kDa}$, exhibiting $79 \%$ and $70 \%$ identity to the Echr and E. coli DsbA proteins, respectively. The Ecc and Eca DsbA proteins displayed $96 \%$ identity. 


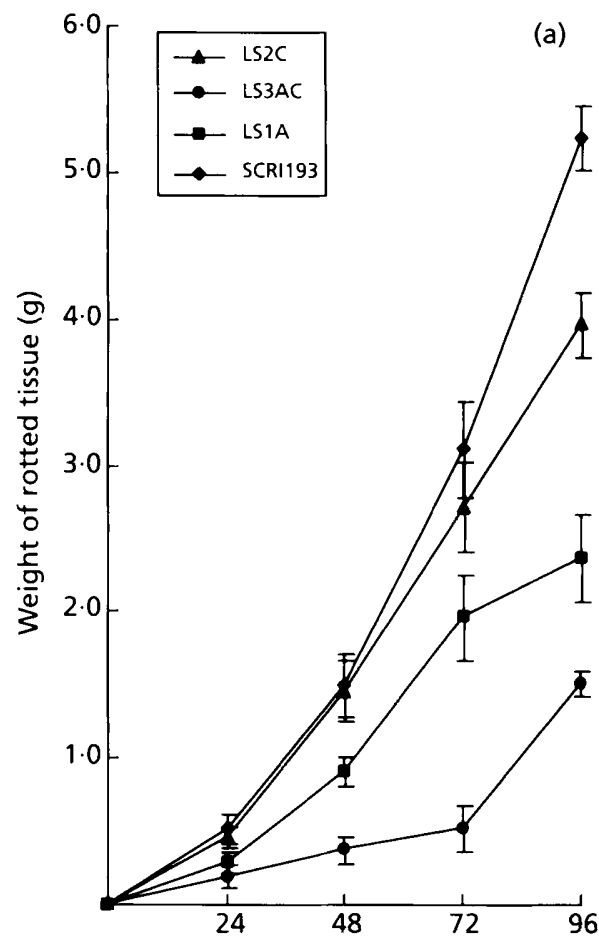

(a)

Time (h)
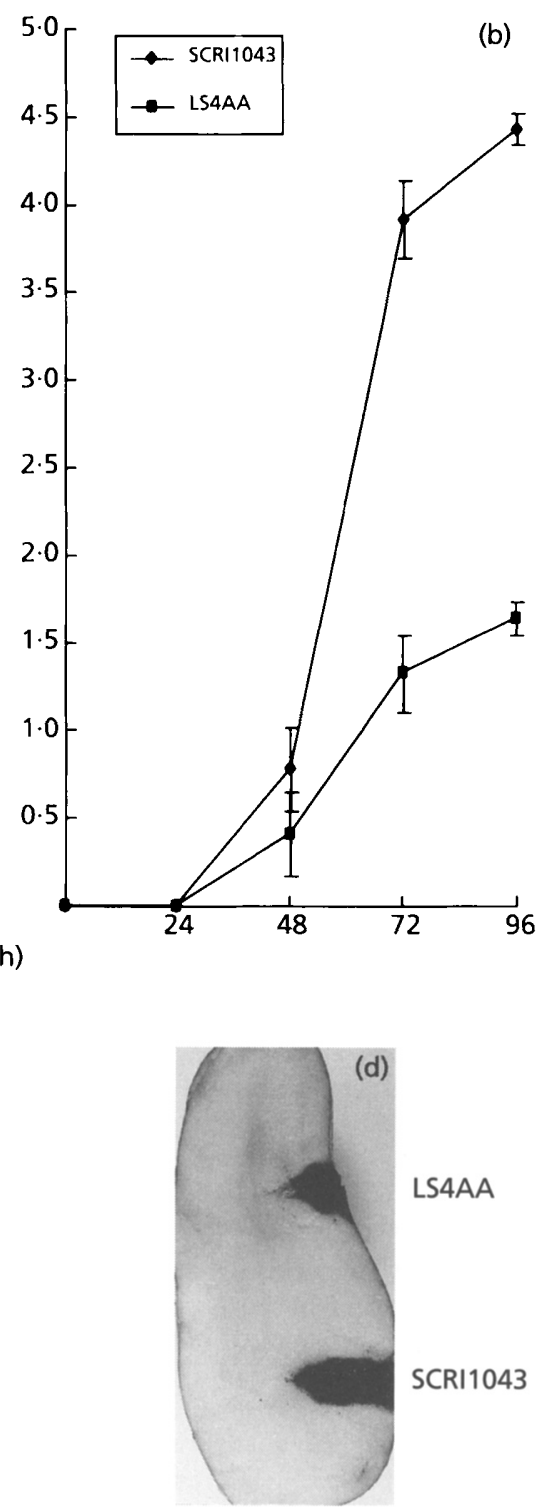

Fig. 2. Virulence assay of Dsb strains of Ecc (LS1A, LS2C and LS3AC) and Eca (LS4AA) on potato tubers. The Ecc and Eca wild-type strains, SCRI193 and SCRI1043, respectively, were used as controls. (a, b) Results expressed as the mean value of six replicas of each strain for each time point. (c, d) Cavities of tubers stained for contrast with Lugol's iodine. (a, c) Ecc strains assayed on tubers of cultivar Colmo Tops; (b, d) Eca strains assayed on tubers of cultivar Pentland Javelin.

\section{DNA sequence analysis of the Ecc yihE gene and the yihE/dsbA distal promoter}

The sequence data from $\mathrm{pBH}$ and $\mathrm{pBAT}$ revealed the presence of incomplete ORFs 236 and 127 bp in length, only $27 \mathrm{bp}$ upstream of, and transcribed in the same orientation as, the Ecc and Eca dsbA genes, respectively. These ORFs encoded two virtually identical putative Cterminal truncated proteins with strong homology to the C-terminal region of the E. coli YihE protein (Blattner $e t$ al., 1997). Thus, the organization of the $d s b / y i b E$ region is similar in all three organisms (see Fig. 1).

In E. coli, the $d s b A$ gene is expressed via two promoters, a proximal promoter (P1) directly upstream of the $d s b A$ gene and a distal promoter (P2) upstream of yihE (Belin
\& Boquet, 1994), and the latter of these is positively regulated by the $\mathrm{CpxA} / \mathrm{R}$ two-component regulator (Pogliano et al., 1997). CpxR regulates several genes whose protein products are associated with folding and misfolding of proteins in the periplasm. A CpxR consensus binding site has been identified in the promoter regions of several of these genes, including the $E$. coli dsbA P2 promoter (Pogliano et al., 1997; Nakayama \& Watanabe, 1998). The Ecc $d s b A$ gene 5 region did not contain a putative CpxR-binding site. The subclone pHIN was also sequenced. As expected, pHIN contained sequence encoding the $5^{\prime}$ region of the Ecc yihE gene (GenBank accession no. AF146615), but the promoter region of Ecc yibE showed no consensus CpxR-binding site (data not shown). 


\section{DNA sequence analysis of the Ecc dsbC gene}

Preliminary sequence data analysis of the fragment from $\mathrm{pHH}$ revealed that it did not carry the complete Ecc $d s b C$ gene so the sequence was extended using the original cosmid, cM2. The data were compiled into a contiguous sequence of $1186 \mathrm{bp}$ (GenBank accession no. AF146614) containing an ORF of 714 nucleotides, beginning at residue 315 and ending at residue 1028 . This ORF encoded a predicted protein of 238 amino acids, with an $M_{\mathrm{r}}$ of $25.7 \mathrm{kDa}$, and exhibiting $70 \%$ and $58 \%$ identity to the Echr and E. coli DsbC proteins, respectively.

Like the DsbA and DsbC proteins previously reported, the Ecc equivalents are predicted to have a signal sequence indicating export to the periplasm as well as the characteristic-C-X-X-C-motif, confirming them as members of the disulfide oxidoreductase protein family. Since the C-terminal truncated protein encoded by $\mathrm{pH}$ (incomplete $d s b C$ gene) fully complemented the DsbC mutant, the six amino acids at the carboxy terminus of Ecc $d s b C$ (-S-K-K-T-G-G-) are not essential for function.

The sequence data also revealed the presence of an incomplete ORF (186 bp), upstream of, and transcribed in the same orientation as, DsbC, which encoded a Cterminal truncated protein with significant homology to XerD of E. coli and Haemophilus influenzae $(44 \%$ and $50 \%$ identity, and $55 \%$ and $55 \%$ similarity, respectively). Downstream of DsbC, a second incomplete ORF was identified (143 bp), which encoded the N-terminal region of a protein with significant homology to the RecJ proteins of Echr and E. coli $(67 \%$ and $76 \%$ identity, and $82 \%$ and $61 \%$ similarity, respectively). All three genes are thought to form part of the same operon in E. coli and Echr (Blakely \& Sherratt, 1994; Missiakas et al., 1994).

\section{Marker exchange mutagenesis of the Ecc dsbA and $d s b C$ genes and the Eca dsbA gene}

In order to investigate the role of the Dsb proteins in exoenzyme activity and secretion in Ecc, and in motility in Eca, marker exchange mutagenesis was done for all three Erwinia ds $b$ genes (see Methods). The genotype of the resulting mutants (LS1A, Ecc dsbA::gusA/Cm ${ }^{\mathrm{R}}$; LS2C, Ecc $d s b C:: g u s A / \mathrm{Kn}^{\mathrm{R}}$; LS4AA, Eca $d s b A:$ : gus $A / \mathrm{Cm}^{\mathrm{R}}$ ) was confirmed by Southern blot analysis (data not shown). A double $d s b A d s b C$ mutant of Ecc (LS3AC) was created using the Ecc-specific transducing phage, $\phi \mathrm{KP}$ (see Methods), and Southern blot analysis confirmed the presence of both mutated genes in this strain (data not shown). None of the $d s b$ mutants was impaired in growth rate or total protein content in comparison to the wild-type strains (data not shown).

\section{Virulence of Ecc and Eca dsb mutants}

Potato tuber virulence assays were performed on Ecc and Eca Dsb mutants using the cultivars Colmo Tops and Pentland Javelin, respectively, and the results are shown in Fig. 2. A $52 \%, 28 \%, 86 \%$ and $63 \%$ reduction

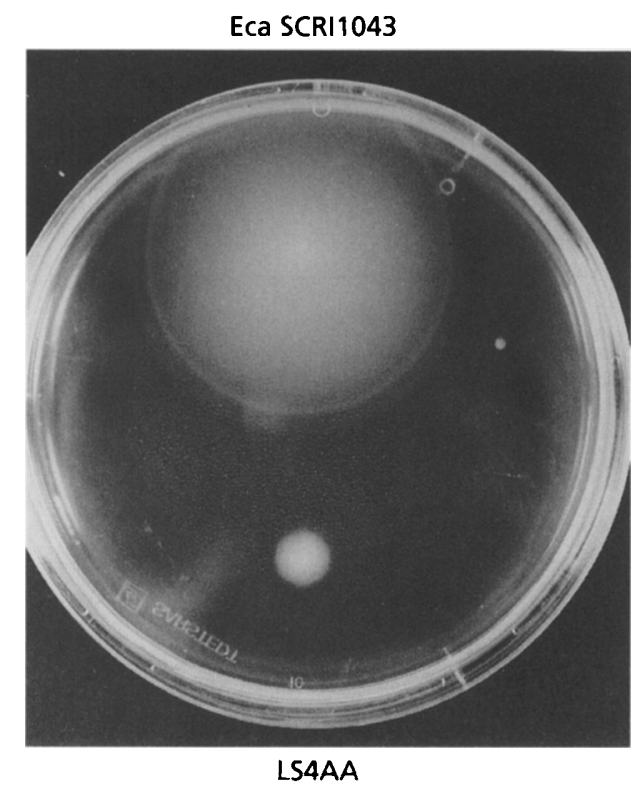

Fig. 3. Motility of wild-type Eca SCRI 1043 and LS4AA.

in the ability to cause rotting was observed for LS1A, LS2C, LS3AC and LS4AA, respectively when compared to the wild-type strain. Each assay was also performed on the cultivar Maris Piper with similar results. The reduced rotting capacity of these strains implied that the Dsb system is essential for the activity of virulence factors, probably Pel and Peh, in Ecc and Eca. However, the fact that all $d s b$ mutant strains were able to produce some degree of maceration indicated that other DsbAindependent virulence factors were operating.

\section{The Ecc dsbA gene is essential for motility}

Earlier experiments in this laboratory have shown motility to be an important virulence determinant in Eca (Harris et al., 1998; Mulholland et al., 1993). Therefore, we assessed the motility of the Eca strain LS4AA (Fig. 3). The mean diameter of LS4AA colonies was $8 \mathrm{~mm}$ whilst that of the wild-type, SCRI1043, was $45 \mathrm{~mm}$. Since halo size represents an exponential function, the reduced halo observed for LS4AA represents a $>82 \%$ reduction in motility and suggests that disulfide bond formation is a prerequisite for motility of Eca. The residual motility in this strain was due to the activity of the chromosomal copy of the $d s b C$ gene (Pugsley, 1992), as shown by restoration of full motility when the Ecc $d s b C$ gene was expressed in trans from $\mathrm{pHH}$ in LS4AA (data not shown).

\section{Enzymic activity in Ecc dsb mutants}

Cellular fractions (supernatant, periplasm and cytoplasm) were prepared from LS1A, LS2C, LS3AC and wild-type Ecc SCRI193, and analysed for the secretion and activity of Prt, Pel, Peh and Cel (Table 2). More than $90 \%$ of the total Prt activity of each Ecc $d s b$ mutant was 
Table 2. Enzyme localizations of Ecc Dsb mutants

Samples were fractionated into supernatant $(\mathrm{S})$, periplasm $(\mathrm{P})$ and cytoplasm $(\mathrm{C})$, and all enzyme assays were carried out in triplicate and performed at least twice. Total enzyme activities (T) were calculated as the sum of the absolute enzyme activity in each fraction: Prt, $\Delta \mathrm{OD}_{436} \mathrm{units} \mathrm{h}^{-1} \mathrm{ml}^{-1}$; Pel, $\Delta \mathrm{OD}_{23,5}$ units $\mathrm{min}^{-1} \mathrm{ml}^{-1}$; Peh, $\Delta \mathrm{OD}_{500}$ units $\min ^{-1} \mathrm{ml}^{-1}$; Cel, $\Delta \mathrm{OD}_{623}$ units $\mathrm{min}^{-1} \mathrm{ml}^{-1}$. The activities of each fraction are expressed as a percentage of the total enzyme activity.

\begin{tabular}{|c|c|c|c|c|c|c|c|c|c|c|c|c|c|c|c|c|}
\hline \multirow[t]{2}{*}{ Strain } & \multicolumn{4}{|c|}{ Prt } & \multicolumn{4}{|c|}{ Pel } & \multicolumn{4}{|c|}{ Peh } & \multicolumn{4}{|c|}{ Cel } \\
\hline & $\mathbf{T}$ & $\mathrm{S}$ & $\mathbf{P}$ & $\mathrm{C}$ & $\mathrm{T}$ & $S$ & $\mathbf{P}$ & $\mathrm{C}$ & $\mathrm{T}$ & $S$ & $\mathbf{P}$ & $\mathrm{C}$ & $\mathbf{T}$ & $S$ & $P$ & $\mathrm{C}$ \\
\hline SCRI193 & $11 \cdot 29$ & 97 & 2 & 1 & $19 \cdot 71$ & 97 & 2 & 1 & $0 \cdot 22$ & 100 & 0 & 0 & 0.47 & 75 & 23 & 2 \\
\hline LSIA & $10 \cdot 84$ & 93 & 4 & 3 & $0 \cdot 83$ & 15 & 48 & 37 & $0 \cdot 08$ & 12 & 0 & 88 & $0 \cdot 87$ & 47 & 49 & 4 \\
\hline LS2C & $11 \cdot 40$ & 92 & 5 & 3 & $20 \cdot 61$ & 98 & 2 & 0 & $0 \cdot 28$ & 100 & 0 & 0 & $0 \cdot 50$ & 84 & 14 & 2 \\
\hline LS3AC & $3 \cdot 95$ & 95 & 2 & 3 & $1 \cdot 11$ & 24 & 48 & 28 & 0.07 & 14 & 0 & 86 & 1.43 & 32 & 36 & 32 \\
\hline
\end{tabular}

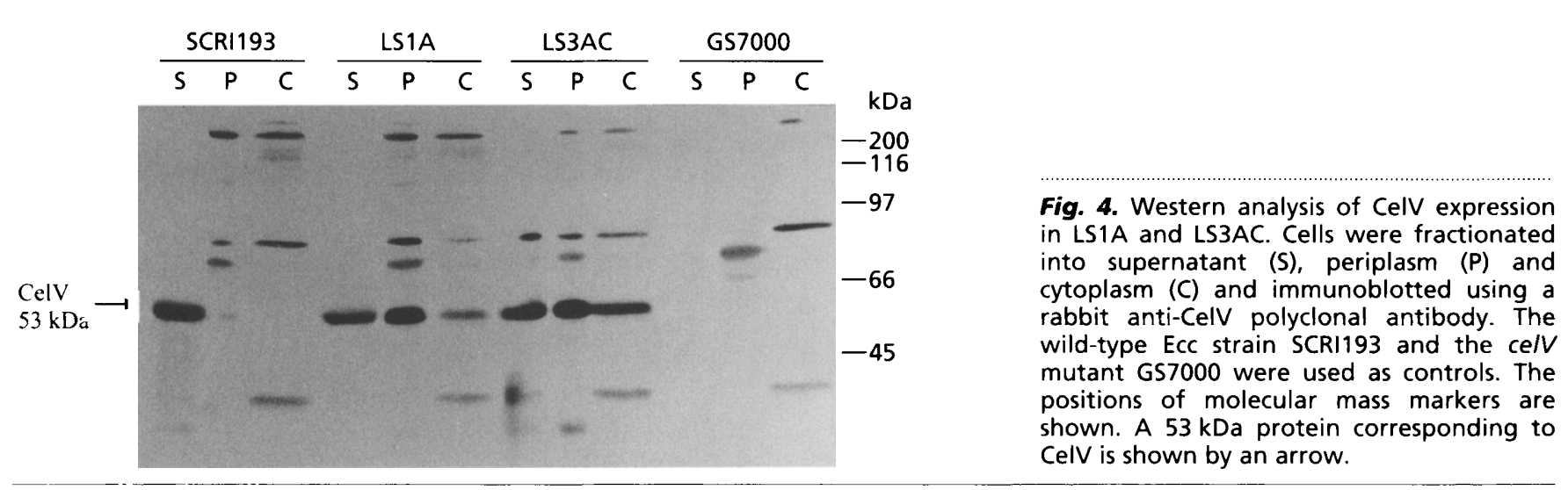

detected in the supernatant. Since Prt is secreted normally in these strains, and the membrane fusion proteins (e.g. Echr PrtE; Delepelaire \& Wandersman, 1991) are the only type I apparatus components with large periplasmic domains, which also generally lack cysteines, this implies that the type I components are probably not disulfide-bonded and achieve their functional state in a Dsb-independent manner. Although the total Prt activity of LS3AC was reduced to $35 \%$ of the wild-type level, neither of the single mutations affected the total level of Prt activity, suggesting that an active $d s b C$ gene might rescue the $d s b A$ mutation of LS1A and vice versa.

Immunoblot analysis with an antibody specific to a $53 \mathrm{kDa}$ metalloprotease of Ecc SCRI177 (Heilbronn et al., 1995) was performed on cell fractions to determine if the reduced level of total Prt activity in LS3AC was due to catalytically inactive enzyme. However, a $46 \mathrm{kDa}$ protein was detected in all supernatant fractions except LS3AC (data not shown), but not the other fractions, implying that this protein was either degraded or not produced in LS3AC.

At least three Prt have been purified from various strains of Ecc (Smith et al., 1987; Kyostio et al., 1991; Heilbronn et al., 1995), but the number and secretability of isozymes in Ecc SCRI193 is not known. However, reduction in Prt secretion/production due to Dsb effects is not without precedent among bacterial pathogens, and Prt deficiency of $d s b$ mutants has been reported for several strains, including Echr (Peek \& Taylor, 1992; Shevchik et al., 1994; Abe \& Nakazawa, 1996). Interestingly, Prt1 of Ecc strain EC14 (Kyostio et al., 1991) has a typical sec-dependent signal sequence, implying it may be a type-II-targeted protein, and contains three cysteine residues. Therefore, the protein detected here might be the Prt1 equivalent in Ecc SCRI193. Nonetheless, the contribution of this protein to total Prt activity in Ecc is likely to be minor since Prt secretion appears to be normal in Ecc Out ${ }^{-}$mutants (Reeves et al., 1993).

Total Pel activity of LS1A and LS3AC was reduced to $4 \%$ and $6 \%$ of the wild-type level, respectively, whilst the level of Pel activity in LS2C was essentially that of the wild-type (Table 2). In addition, almost $100 \%$ of the Pel activity of the wild-type and LS2C were secreted to the supernatant. It is likely that the reduced activity observed in the $\mathrm{DsbA}^{-}$strains is due to improper folding of one of the major Pel isozymes, PelC. Mis- or unfolded proteins in the periplasm are often degraded by periplasmic proteases (Shevchik et al., 1995; Yu et al., 1992); therefore the reduced Pel activity in the DsbA ${ }^{-}$strains might result from periplasmic PelC intermediates being locked in an inactive misfolded form, which is degraded. 

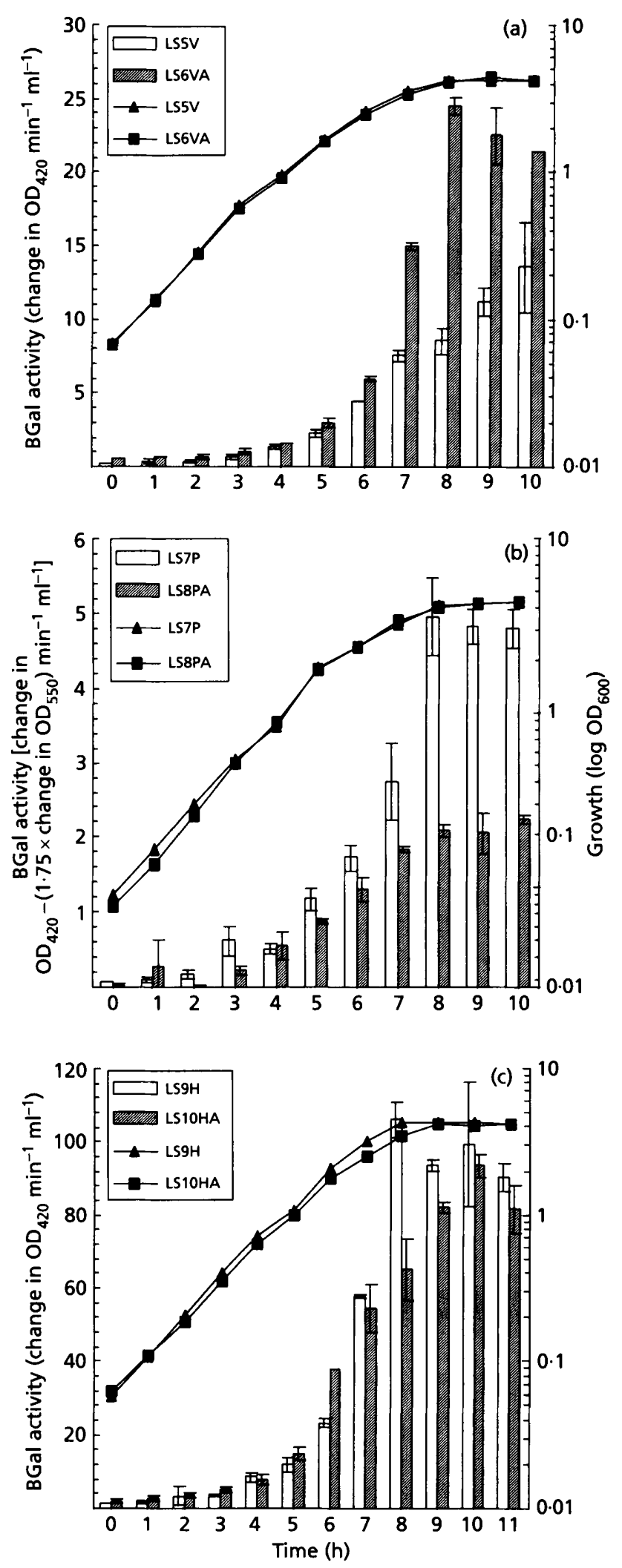

Fig. 5. The expression of CelV, PelC and Peh \pm DsbA. Strains were grown in PMB at $30^{\circ} \mathrm{C}$ and growth and BGal activity were monitored at hourly intervals. Cell growth (black triangles and squares) is expressed as $\log \mathrm{OD}_{600}$. BGal activity (white and hatched bars) is expressed as change in $O D_{420} \mathrm{~min}^{-1} \mathrm{ml}^{-1}$ and
The residual Pel activity in these strains may be attributed to other Pel that fold in a Dsb-independent fashion. The wild-type levels of Pel activity recorded for LS2C imply that mutation in $d s b C$ alone is insufficient to prevent disulfide bond formation in PelC and PelD and supports the notion that DsbA is the major contributor to disulfide bond formation in the bacterial periplasm. It is also consistent with the view that DsbC is of greater importance to those proteins that possess several disulfide bonds.

The total Peh activity of LS1A and LS3AC was $36 \%$ and $32 \%$, respectively, that of the wild-type, whilst LS2C had essentially wild-type activity. In both LS2C and the wild-type, Peh activity was found only in the supernatant. Therefore, the mutation in $d s b C$ had no effect on Peh secretion. However, the location of $88 \%$ and $86 \%$ of the Peh activity in LS1A and LS3AC, respectively, in the cytoplasmic fractions (Table 2) was surprising since, in the absence of DsbA, Peh was predicted to remain export-competent, and any mis- or unfolded species in the periplasm were predicted to be degraded. Crosscontamination of the cell fractions was unlikely since $\sim 90 \%$ of the activity of the periplasmic and cytoplasmic enzyme markers was correctly located (data not shown). In the absence of DsbA Peh, disulfide bonds might form in the cytoplasm. The reduced environment of the cytoplasm means that this is an unusual, although not unprecedented (Nilsson et al., 1991), phenomenon. A recent report on disulfide bond formation in bacterial proteins suggests that we may need to reassess our views on folding of cytoplasmic proteins containing cysteine residues (Stewart et al., 1998).

CelV contains no cysteines (Cooper \& Salmond, 1993) and hence no disulfide bonds, and was originally intended as a control in examining the effect of disulfide bond deficiency on the Ecc type II apparatus. If a Dsb ${ }^{-}$ strain was unable to secrete CelV this would indicate an effect on the type II apparatus itself. Therefore, we were surprised to find that the total Cel activity of the $\mathrm{Dsb}^{-}$ strains was $\sim$ two- to threefold greater than that of the wild-type (Table 2). LS2C displayed a wild-type phenotype, and in both LS2C and SCRI193 $75-84 \%$ of total Cel activity was found in the supernatant. By contrast, in LS1A and LS3AC there was an almost equal distribution of Cel activity among the supernatant and the periplasm, and the three cellular fractions, respectively. These data provide conclusive evidence that the type II proteins are not affected by mutation in $d s b A$ or $d s b C$ since wild-type amounts of Cel were secreted normally.

To verify that the observed Cel activity was due to the presence of CelV, immunoblot analysis of cell fractions was carried out using a rabbit polyclonal antibody raised against the purified CelV protein (Walker et al., 1994; Fig. 4). The wild-type strain SCRI193, and

the mean value of three replicas is shown. (a) LS5V, celV::lacZ; LS6VA, celV::lacZ dsbA::gusA/Cm ${ }^{\mathrm{R}}$. (b) LS7P, pe/C::lacZ; LS8PA, pelC::lacZ dsbA::gusA/Cm ${ }^{R}$. (c) LS9H, peh::lacZ; LS10HA, peh::lacZ dsbA::gusA $/ \mathrm{Cm}^{\mathrm{R}}$. 
GS7000, a CelV ${ }^{-}$derivative, were used as positive and negative controls, respectively. CelV was observed as a $53 \mathrm{kDa}$ protein exclusively in the extracellular fraction of SCRI193. However, CelV was observed in all fractions of the DsbA- mutants LS1A and LS3AC. More than $50 \%$ of CelV was cell-associated in these strains, confirming that the increased levels of Cel activity previously observed in the periplasm and cytoplasm of LS1A and LS3AC was due to overproduction of the CelV protein.

We have previously observed that CelV accumulates in the periplasm and cytoplasm of Ecc when it is expressed at high levels (Cooper \& Salmond, 1993; Walker et al., 1994). Assuming folded Cel molecules require recognition by the Out apparatus prior to secretion, accumulation of CelV in the periplasm might be explained by saturation of the apparatus. However, this might also be expected to result in an indirect effect on Pel secretion, yet none was observed. Walker et al. (1994) suggested that accumulation of CelV in the cytoplasmic fraction might be due to the formation of Cel aggregates that render the enzyme non-secretable. The apparently high level in the 'cytoplasm' would then be artefactual, due to the inability of Cel aggregates to dissociate from the inner membrane during removal of the periplasmic fraction, but which are released into the cytoplasm during sonication.

\section{Analysis of an Ecc celV: :lacZ transcriptional fusion}

The $\sim$ two- to threefold increase in Cel activity caused by the mutation in $d s b A$ was surprising and warranted further investigation. Two hypotheses were tested: firstly, that in the absence of functional DsbA a cryptic Cel is induced, and secondly, that an increase in the transcription of celV in the $d s b A$ background might result in greater production of CelV and its accumulation in the cell. To test the latter, a lac $Z$ transcriptional fusion was created in $c e l V$ which, in addition to causing a mutation so that any novel cryptic Cel might become apparent, allowed for monitoring the transcription of celv.

The construct $\mathrm{pVicLK}$, carrying a celV-lacZ transcriptional fusion, was created and used to replace the wildtype celV gene of MH1000 (a $\mathrm{Lac}^{-}$derivative of SCRI193). The genotype of the resulting $\mathrm{Cel}^{-}$strain, LS5V, was confirmed by Southern blot analysis (data not shown). A double $c e l v d s b A$ mutant of Ecc, LS6VA, was created using $\phi \mathrm{KP}$. Cell fractions from both strains were assessed on Cel detection media and neither strain produced detectable Cel activity (data not shown). This showed that no cryptic Cel is induced in the DsbAdeficient strain, and implied that some other phenomenon must be responsible for the increased Cel activity observed in LS1A and LS3AC.

To investigate whether the transcription of $c e l V$ is upregulated in a $d s b A$ background, lac $Z$ expression was monitored for the LS5V and LS6VA mutants (Fig. 5a). There was no difference in the growth rates, nor in the total protein content (data not shown), of the strains.
However, the difference in the level of expression of the celV-lacZ transcriptional fusion in the wild-type and DsbA-deficient backgrounds was quite marked. Throughout growth the expression of celV was greater in LS6VA than in LS5V. This ranged from a $15 \%(4 \mathrm{~h})$ to a $162 \%(9 \mathrm{~h})$ increase. The maximum level of celV expression in the wild-type background was observed at $8 \mathrm{~h}$.

The regulation of exoenzymes in Erwinia species is extremely complex, being affected by both intrinsic and environmental factors (Barras et al., 1994). Exoenzyme production is induced during late exponential growth (Hugouvieux-Cotte-Pattat et al., 1986, 1992; Boyer et al., 1984; Aymeric et al., 1988). The molecular mechanism for this cell-density-dependent gene regulation in Ecc centres on the production of a small diffusible molecule, $N$-(3-oxohexanoyl)-L-homoserine lactone (OHHL; Jones et al., 1993). The dramatic increase in the transcription of celV in the DsbA-deficient strain raised the question as to whether similar transcriptional up-regulation was taking place with the other exoenzymes. These displayed reduced activity in the $d s b A$ background and were thought to be degraded, hence exoenzyme assays could not indicate if there was an increased transcription. It was therefore necessary to compare the transcription of both pelC and peh in a wild-type and $d s b A$ background.

\section{Analysis of Ecc pe/C::lacZ and peh::lacZ transcriptional fusions}

The constructs pJSLK and pESLK were produced and used to create chromosomal lac $Z$ transcriptional fusions in the pelC (LS7P) and peh (LS9H) genes of MH1000. The genotypes of the resulting mutants were confirmed by Southern blot analysis (data not shown) and fusions were transduced into a $d s b A$ background to produce LS8PA and LS10HA. The transcription of pelC and peh was analysed in the wild-type and $d s b A$ background as described for celV. None of the strains showed an appreciable difference in either growth rate (Fig. $5 \mathrm{~b}$ and c) or protein content (data not shown).

A difference in the level of transcription of pelC in the wild-type and $d s b A$ backgrounds was evident (Fig. 5b). Transcription appeared to be slightly higher in LS8PA than in LS7P at 1 and $4 \mathrm{~h}$. After $5 \mathrm{~h}$, the level of transcription in LS7P was consistently higher than that in LS8PA. Between 6 and $10 \mathrm{~h}$ there was $\sim 50 \%$ decrease in the transcriptional level of pelC in LS8PA compared to LS7P. This is unlike the transcription of celV, indicating that genes encoding two enzymes secreted by the Out pathway are differentially affected by the $d s b A$ mutation.

Although the expression of peh in the wild-type background appeared to lag slightly behind that in the DsbAdeficient strain during the early stages of growth, a dramatic induction of peh expression in the wild-type took place after $8 \mathrm{~h}$. At this point the BGal expression in the wild-type background was $\sim 64 \%$ greater than that 
in the $d s b A$ background. This trend continued into the stationary phase although the difference was less marked $(\sim 12 \%)$. This indicates that the $d s b A$ mutation causes a down-regulation of peh transcription.

\section{Regulation of the Ecc exoenzymes is not mediated by a single agent}

Several factors which appear to co-ordinately regulate exoenzyme production during the late post-exponentialgrowth phase have been identified in Ecc. These include: (i) OHHL (Jones et al., 1993; Pirhonen et al., 1993); (ii) pectate and other plant signals (Liu et al., 1993); (iii) activation genes, variously designated aep (Liu et al., 1993), exp (Pirhonen et al., 1991) and rex (Jones et al., 1993), thought to encode regulatory proteins; and (iv) negative regulators, such as the Ecc $r s m A$ gene product, which represses extracellular enzyme production and other metabolic functions in Erwinia species (Mukherjee et al., 1996).

However, the results presented here indicate a differential expression of exoenzymes in the DsbA-deficient strain: celV increased by $\sim 200 \%$, pelC decreased by $\sim 50 \%$ and peh decreased by $\sim 60$ to $\sim 12 \%$ from late exponential to stationary phase. This implies that the regulatory effect on transcription of these genes is unlikely to be mediated via a single agent. It is interesting that transcription of pelC and peh, both predicted to be disulfide-bonded, appear to respond in a similar manner. A $d s b A$ mutation deprives the periplasm of DsbA, whose role is to catalyse disulfide bond formation in this compartment. Our results therefore indicate that what is essentially a periplasmic event is having an effect (presumably indirect) on gene transcription in the cytoplasm. This implies the operation of a signal transduction feedback mechanism linking periplasmic protein stability with transcription.

Recent reports have identified protein misfolding in the periplasm (as caused by $d s b$ mutation) as a stimulus that can trigger up-regulation of other genes in E. coli. For example, Missiakas \& Raina (1997) reported that protein misfolding in the periplasm leads to up-regulation of $\operatorname{degP}$ (which encodes a periplasmic Prt that degrades misfolded proteins in the periplasm) via $\sigma^{\mathrm{E}}$, the second heat shock-inducible sigma factor. In E. coli, $\operatorname{deg} P$ expression is regulated by the $\mathrm{CpxA} / \mathrm{R}$ twocomponent regulator (Danese et al., 1995), which also regulates proteins involved in periplasmic folding (e.g. DsbA; Danese \& Silhavy, 1997). Intriguingly, in an independent study we have identified a role for CpxA in the regulation of Pel in Ecc (unpublished data); evidently, a regulatory network similar to the one in E. coli is in effect in Ecc.

\section{Concluding remarks}

The results of this study are consistent with the notion that the ability of Erwinia spp. to cause virulence results from a series of tightly co-ordinated events, including exoenzyme synthesis and secretion in Ecc, and motility in Eca. Two inferences can be made. Firstly, the Dsb system has no effect on the type II secretion system. Secondly, the Dsb system plays a role in feedback signal transduction on transcription, resulting in differential expression of exoenzymes. Interestingly, the DsbA effect can be mimicked by DTT treatment (data not presented). We also observed that mutation in $d s b C$ alone does not affect the phenotypes assessed, and, except in the case of Prt production and tissue maceration, the deficient phenotypes seem to be due to mutation in $d s b A$ alone. This is consistent with the findings of Shevchik et al. (1994) for Echr. Future work will focus on the molecular nature of the feedback signal transduction and its ability to differentially affect exoenzyme synthesis.

\section{ACKNOWLEDGEMENTS}

This work was supported by BBSRC funding (P06812) to GPCS. Lois Vincent-Sealy was funded by a Commonwealth Scholarship. We thank Gary Lyon for antibodies and Michele Bentley for assistance with the manuscript.

\section{REFERENCES}

Abe, M. \& Nakazawa, T. A. (1996). The $d s b B$ gene product is required for protease production by Burkbolderia cepacia. Infect Immun 64, 4378-4380.

Andro, T., Chambost, J.-P., Kotoujansky, A., Cattaneo, J., Bertheau, Y., Barras, F., van Gijsegem, F. \& Coleno, A. (1984). Mutants of Erwinia chrysanthemi defective in secretion of pectinase and cellulase. J Bacteriol 160, 1199-1203.

Atling-Mees, M. A. \& Short, J. M. (1989). pBluescript II : gene mapping vectors. Nucleic Acids Res 17, 9494.

Aymeric, J. L., Guiseppi, A., Pascal, M. C. \& Chippaux, M. (1988). Mapping and regulation of the cel genes in Erwinia chrysanthemi. Mol Gen Genet 211, 95-101.

Bardonnet, N. \& Blanco, C. (1992). uidA antibiotic resistance cassettes for insertion mutagenesis, gene fusion and genetic construction. FEMS Microbiol Lett 93, 243-248.

Bardwell, J. C. A. (1994). Building bridges: disulfide bond formation in the cell. Mol Microbiol 14,199-205.

Bardwell, J. C. A., McGovern, K. \& Beckwith, J. (1991). Identification of a protein required for disulfide bond formation in vivo. Cell 67, 581-585.

Barras, F., van Gijsegem, F. \& Chatterjee, A. K. (1994). Extracellular enzymes and pathogenesis of soft-rot Erwinia. Annu Rev Phytopathol 32, 201-234.

Belin, P. \& Boquet, P. L. (1994). The Escherichia coli dsbA gene is partly transcribed from the promoter of a weakly expressed upstream gene. Microbiology 140, 3337-3348.

Blakely, G. W. \& Sherratt, D. J. (1994). Interactions of the sitespecific recombinases XerC and XerD with the recombination site dif. Nucleic Acids Res 22, 5613-5620.

Blattner, F. R., Plunkett, G., III, Bloch, C. A. \& 14 other authors (1997). The complete genome sequence of Escherichia coli K-12. Science 277, 1453-1474.

Bleves, S., Lazdunski, A. \& Filloux, A. (1996). Membrane topology of three Xcp proteins involved in exoprotein transport by Pseudomonas aeruginosa. J Bacteriol 178, 4297-4300. 
Bolivar, F., Rodriguez, R. C., Greene, P. J., Betlach, M. C., Heyneker, H. L. \& Boyer, H. W. (1977). Construction and characterisation of new cloning vehicles. II. A multipurpose cloning system. Gene 2, 95-113.

Bortolli-German, I., Brun, E., Py, B., Chippaux, M. \& Barras, F. (1994). Periplasmic disulfide bond formation is essential for cellulase secretion by the plant pathogen Erwinia chrysanthemi. Mol Microbiol 11, 545-553.

Boyer, M. H., Chambost, J. P., Magnan, M. \& Cattaneo, J. (1984). Carboxymethyl-cellulase from Erwinia chrysanthemi. I. Production and regulation of extracellular carboxymethyl-cellulase. J Biotechnol 1, 229-239.

Brumlik, M. J., van der Goot, F. G., Wong, K. R. \& Buckley, J. T. (1997). The disulfide bond in the Aeromonas bydrophila lipase/ acyltransferase stabilises the structure but is not required for secretion or activity. J Bacteriol 179, 3116-3121.

Cooper, V. J. C. \& Salmond, G. P. C. (1993). Molecular analysis of the major cellulase (CelV) of Erwinia carotovora: evidence for an evolutionary 'mix-and-match' of enzyme domains. Mol Gen Genet 241, 341-350.

Danese, P. N. \& Silhavy, T. J. (1997). The $\sigma^{\text {E }}$ and the Cpx signal transduction system control the synthesis of periplasmic proteinfolding enzymes in Escherichia coli. Genes Dev 11, 1183-1193.

Danese, P. N., Snyder, W. B., Coxma, C. L., Davis, L. J. B. \& Silhavy, T. J. (1995). The Cpx two-component signal transduction pathway of Escherichia coli regulates transcription of the gene specifying the stress-inducible periplasmic protease, DegP. Genes Dev 9, 387-398.

Delepelaire, P. \& Wandersman, C. (1991). Characterisation, localisation and transmembrane organisation of the three proteins PrtD, PrtE and PrtF necessary for protease secretion by the Gramnegative bacterium Erwinia chrysanthemi. Mol Microbiol 5, $2427-2434$

Forbes, K. J. \& Perembelon, M. C. M. (1985). Chromosomal mapping in Erwinia carotovora subspecies carotovora with IncP plasmid R68:: Mu. J Bacteriol 164, 1110-1116.

Foreman, D. T., Martinez, Y., Coombs, G., Torres, A. \& Kupersztoch, Y. M. (1995). TolC and DsbA are needed for the secretion of $\mathrm{ST}_{\mathrm{B}}$, a heat-stable enterotoxin of Escherichia coli. Mol Microbiol 18, 237-245.

Grinter, N. J. (1983). A broad-host-range cloning vector transposable to various replicons. Gene 21, 133-143.

Guiseppi, A., Cami, B., Aymeric, J.-L., Ball, G. \& Creuzet, N. (1988). Homology between endoglucanase $\mathrm{Z}$ of Erwinia chrysanthemi and endoglucanases of Bacillus subtilis and alkalophilic Bacillus. Mol Microbiol 2, 159-164.

Hardie, K. R., Schulze, A., Parker, M. W. \& Buckley, J. T. (1995). Vibrio spp. secrete proaerolysin as a folded dimer without the need for disulphide bond formation. Mol Microbiol 17, 10351044.

Hardy, S. J. S., Holmgren, J., Johansson, S., Sanchez, J. \& Hirst, T. R. (1988). Co-ordinated assembly of multisubunit proteins: oligomerisation of bacterial enterotoxins in vivo and in vitro. Proc Natl Acad Sci USA 85, 7109-7113.

Harris, S. J., Shih, Y.-L., Bentley, S. D. \& Salmond, G. P. C. (1998). The hexA gene of Erwinia carotovora encodes a LysR homologue and regulates motility and the expression of multiple virulence determinants. Mol Microbiol 28, 705-717.

Heilbronn, J., Johnston, D. J., Dunbar, B. \& Lyon, G. D. (1995). Purification of a metalloprotease produced by Erwinia carotovora ssp. carotovora and the degradation of potato lectin in vitro. Physiol Mol Plant Pathol 47, 285-292.
Herrero, M., de Lorenzo, V. \& Timmis, K. N. (1990). Transposon vectors containing non-antibiotic resistance selection markers for cloning and stable chromosomal insertion of foreign genes. J Bacteriol 172, 6557-6567.

Hinton, J. C. D. \& Salmond, G. P. C. (1987). Use of TnphoA to enrich for extracellular enzyme mutants of Erwinia carotovora subspecies carotovora. Mol Microbiol 1, 381-386.

Hinton, J. C. D., Sidebotham, J. M., Gill, D. R. \& Salmond, G. P. C. (1989). Extracellular and periplasmic isoenzymes of pectate lyase from Erwinia carotovora subsp. carotovora belong to different gene families. Mol Microbiol 3, 1785-1795.

Hinton, J. C. D., Gill, D. R., Lalo, D., Plastow, G. S. \& Salmond, G. P. C. (1990). Sequence of the peh gene of Erwinia carotovora: homology between Erwinia and plant enzymes. Mol Microbiol 4, 1029-1036.

Hohn, B. \& Collins, J. (1980). A small cosmid for efficient cloning of large DNA fragments. Gene 11, 291-298.

Hugouvieux-Cotte-Pattat, N., Reverchon, S., Condemine, G. \& Robert-Baudouy, J. (1986). Regulatory mutations affecting the synthesis of pectate lyase in Erwinia chrysanthemi. J Gen Microbiol 132, 2099-2106.

Hugouvieux-Cotte-Pattat, N., Dominguez, H. \& Robert-Baudouy, J. (1992). Environmental conditions affect transcription of the pectinase genes of Erwinia chrysanthemi 3937. J Bacteriol 174, 7807-7818.

Ishihara, T., Tomita, H., Hasegawa, Y., Tsukagoshi, N., Yamagata, H. \& Udaka, S. (1995). Cloning and characterisation of the gene for a protein thiol-disulfide oxidoreductase in Bacillus brevis. J Bacteriol 177, 745-749.

Jones, S., Yu, B., Bainton, N. J. \& 11 other authors (1993). The lux autoinducer regulates the production of exoenzyme virulence determinants in Erwinia carotovora and Pseudomonas aeruginosa. EMBO J 12, 2477-2482.

Kaniga, K., Delor, I. \& Cornelis, G. R. (1991). A wide-host-range suicide vector for improving reverse genetics in Gram-negative bacteria : inactivation of the blaA gene of Yersinia enterocolitica. Gene 109, 137-141.

Kyostio, S. R. M., Cramer, C. L. \& Lacy, G. H. (1991). Erwinia carotovora subsp. carotovora extracellular protease: characterisation and nucleotide sequence of the gene. J Bacteriol 173, $6537-6546$.

Liu, Y., Murata, H., Chatterjee, A. \& Chatterjee, A. K. (1993). Characterisation of a novel regulatory gene aepA that controls extracellular enzyme production in the phytopathogenic bacterium Erwinia carotovora subsp. carotovora. Mol PlantMicrobe Interact 6, 299-308.

Lu, H.-M. \& Lory, S. (1996). A specific targeting domain in mature exotoxin $A$ is required for its extracellular secretion from Pseudomonas aeruginosa. EMBO J 15, 429-436.

McVay, C. S. \& Hamood, A. N. (1995). Toxin A secretion in Pseudomonas aeruginosa: the role of the first 30 amino acids of the mature toxin. Mol Gen Genet 249, 515-525.

Messing, J. \& Vieira, J. (1982). A new pair of M13 vectors for selecting either DNA strand of double-digest restriction fragment. Gene 19, 269-276.

Miller, J. H. (1992). A Short Course in Bacterial Genetics, 2nd edn. Cold Spring Harbor, NY: Cold Spring Harbor Laboratory.

Missiakas, D. \& Raina, S. (1997). Protein folding in the bacterial periplasm. J Bacteriol 179, 2465-2471.

Missiakas, D., Georgopoulos, C. \& Raina, S. (1994). The Escherichia coli dsbC $(x p r A)$ gene encodes a periplasmic protein involved in disulfide bond formation. EMBO J 13, 2013-2020. 
Mukherjee, A., Cui, Y., Liu, Y., Dumenyo, C. K. \& Chatterjee, A. K. (1996). Global regulation in Erwinia species by Erwinia carotovora rsmA, a homologue of Escherichia coli csrR: repression of secondary metabolites, pathogenicity and hypersensitive reaction. Microbiology 142, 427-434.

Mulholland, V., Hinton, J. C. D., Sidebotham, J., Toth, I. K., Hyman, L. J., Perombelon, M. C. M., Reeves, P. J. \& Salmond, G. P. C. (1993). A pleiotropic reduced virulence ( $\left.R v^{-}\right)$mutant of Erwinia carotovora subspecies atroseptica is defective in flagella assembly proteins that are conserved in plant and animal bacterial pathogens. Mol Microbiol 9, 342-356.

Murata, H., Fons, M., Chatterjee, A., Collmer, A. \& Chatterjee, A. K. (1990). Characterisation of transposon insertion $\mathrm{Out}^{-}$ mutants of Erwinia carotovora subsp. carotovora defective in enzyme export and of a DNA segment that complements Out mutants in E. carotovora subsp. carotovora, E. carotovora subsp. atroseptica and E. chrysanthemi. J Bacteriol 172, 2970-2978.

Nakayama, S.-I. \& Watanabe, H. (1998). Identification of $c p x R$ as a positive regulator essential for expression of the Shigella sonnei virF gene. J Bacteriol 180, 3522-3528.

Nilsson, B., Berman-Marks, C., Kuntz, I. D. \& Anderson, S. (1991). Secretion incompetence of bovine pancreatic trypsin inhibition expressed in Escherichia coli. J Biol Chem 266, 2970-2977.

Okamoto, K., Baba, T., Yamanaka, H., Akashi, N. \& Fujii, Y. (1995). Disulfide bond formation and secretion of Escherichia coli heatstable enterotoxin II. J Bacteriol 177, 4579-4586.

Palomaki, T. \& Saarilahti, H. T. (1997). Isolation and characterisation of new C-terminal substitution mutations affecting secretion of polygalacturonase in Erwinia carotovora subsp. carotovora. FEBS Lett 400, 122-126.

Peek, J. K. \& Taylor, R. K. (1992). Characterisation of a periplasmic thiol disulfide interchange protein required for the functional maturation of secreted virulence factors of Vibrio cholerae. Proc Natl Acad Sci USA 89, 6210-6214.

Pirhonen, M., Saarilahti, H. T., Karlsson, M. B. \& Palva, E. T. (1991). Identification of pathogenicity determinants of Erwinia carotovora subsp. carotovora by transposon mutagenesis. Mol Plant-Microbe Interact 4, 276-283.

Pirhonen, M., Flego, D., Heikinheimo, R. \& Palva, E. T. (1993). A small diffusible signal molecule is responsible for the global control of virulence and exoenzyme production in the plant pathogen Erwinia carotovora. EMBO J 12, 2467-2476.

Pogliano, J., Lynch, S., Belin, D., Lin, E. C. C. \& Beckwith, J. (1997). Regulation of Escherichia coli cell envelope proteins involved in protein folding and degradation by Cpx two-component system. Genes Dev 11, 1169-1182.

Pugsley, A. P. (1992). Translocation of a folded protein across the outer membrane in Escherichia coli. Proc Natl Acad Sci USA 89, 12058-12062.

Pugsley, A. P. (1993). The complete general secretory pathway in Gram-negative bacteria. Microbiol Rev 57, 50-108.

Py, B., Chippaux, M. \& Barras, F. (1993). Mutagenesis of cellulase EGZ for studying the general secretory pathway in Erwinia chrysanthemi. Mol Microbiol 7, 785-793.

Reeves, P. J., Whitcombe, D., Wharam, S. \& 9 other authors (1993). Molecular cloning and characterisation of 13 out genes from Erwinia carotovora subspecies carotovora: genes encoding members of a general secretion pathway (GSP) widespread in Gram-negative bacteria. Mol Microbiol 8, 443-456.

Reeves, P. J., Douglas, P. \& Salmond, G. P. C. (1994). Betalactamase topology probe analysis of the OutO NMePhe pep- tidase, and six other Out protein components of the Erwinia carotovora general secretion pathway apparatus. Mol Microbiol $12,445-457$.

Rietsch, A., Belin, D., Martin, N. \& Beckwith, J. (1996). An in vivo pathway for disulfide bond isomerisation in Escherichia coli. Proc Natl Acad Sci USA 93, 13048-13053.

Rodríguez-Peña, J. M., Alvarez, I., Ibáñez, M. \& Rotger, R. (1997). Homologous regions of the Salmonella enteritidis virulence plasmid and the chromosome of Salmonella typhi encode thiol: disulphide oxidoreductases belonging to the DsbA thioredoxin family. Microbiology 143, 1405-1413.

Salmond, G. P. C. (1994). Secretion of extracellular virulence factors by plant pathogenic bacteria. Annu Rev Phytopathol 32, 181-200.

Salmond, G. P. C. \& Reeves, P. J. (1993). Membrane traffic wardens and protein secretion in Gram-negative bacteria. Trends Biochem Sci $18,7-12$.

Sambrook, J., Fritsch, E. F. \& Maniatis, T. (1989). Molecular Cloning: a Laboratory Manual, 2nd edn. Cold Spring Harbor, NY: Cold Spring Harbor Laboratory.

Sanger, F., Nicklen, S. \& Coulson, A. R. (1977). DNA sequencing with chain-termination inhibitors. Proc Natl Acad Sci USA 74, 5463-5467.

Sauvonnet, M. \& Pugsley, A. P. (1996). Identification of two regions of Klebsiella oxytoca pullulanase that together are capable of promoting $\beta$-lactamase secretion by the general secretory pathway. Mol Microbiol 22, 1-7.

Sauvonnet, M. \& Pugsley, A. P. (1998). The requirement for DsbA in pullulanase secretion is independent of disulphide bond formation in the enzyme. Mol Microbiol 27, 661-667.

Selvaraj, G., Fong, Y. C. \& lyer, V. N. (1984). A portable DNA sequence carrying the cohesive site (cos) of bacteriophage lambda and the mob (mobilization) region of the broad-host-range plasmid RK2: a module for the construction of new cosmids. Gene 32, 235-241.

Shevchik, V. E., Condemine, G. \& Robert-Baudouy, J. (1994). Characterisation of DsbC, a periplasmic protein of Erwinia chrysanthemi and Escherichia coli with disulfide isomerase activity. EMBO J 13, 2007-2012.

Shevchik, V. E. , Bortoli-German, I., Robert-Baudouy, J., Robinet, S., Barras, F. \& Condemine, G. (1995). Differential effect of $d s b A$ and $d s b C$ mutations on extracellular enzyme secretion in Erwinia chrysanthemi. Mol Microbiol 16, 745-753.

Silhavy, T. J., Berman, M. L. \& Enquist, L. W. (1984). Experiments with Gene Fusions. Cold Spring Harbor, NY: Cold Spring Harbor Laboratory.

Smith, F. D., Berman, P. M. \& Mount, M. S. (1987). Characterisation of an extracellular protease from Erwinia carotovora subsp. carotovora strain EC14. Phytopathology 77, 122.

Solioz, M. \& Bienz, D. (1990). Bacterial genetics by electric shock. Trends Biochem Sci 15, 175-177.

Stewart, E. J., Aslund, F. \& Beckwith, J. (1998). Disulfide bond formation in the Escherichia coli cytoplasm: an in vivo role reversal for the thioredoxins. EMBO J 17, 5543-5.550.

Thomas, J. D., Reeves, P. J. \& Salmond, G. P. C. (1997). The general secretion pathway of Erwinia carotovora subsp. carotovora: analysis of the membrane topology of OutC and OutF. Microbiology 143, 713-720.

Thomson, N. R., Cox, A., Bycroft, B. W., Stewart, G. S. A. B., Williams, P. \& Salmond, G. P. C. (1997). The Rap and Hor proteins 
of Erwinia, Serratia and Yersinia: a novel subgroup in a growing superfamily of proteins regulating diverse physiological processes in bacterial pathogens. Mol Microbiol 26, 531-544.

Tomb, J.-F. (1992). A periplasmic protein disulfide oxidoreductase is required for transformation of Haemophilus influenzae $\mathrm{Rd}$. Proc Natl Acad Sci USA 89, 10252-10256.

Toth, I., Perombelon, M. \& Salmond, G. (1993). Bacteriophage $\phi \mathrm{KP}$ mediated generalized transduction in Erwinia carotovora subspecies carotowora. J Gen Microbiol 139, 2705-2709.

Walker, D. S., Reeves, P. J. \& Salmond, G. P. C. (1994). The major secreted cellulase, CelV, of Erwinia carotovora subsp. carotovora is an important soft-rot virulence factor. Mol Plant-Microbe Interact 7, 42.5-431.

Wandersman, C. \& Létoffé, S. (1993). Involvement of lipopolysaccharide in the secretion of Escherichia coli $\alpha$-haemolysin and Erwinia chrysanthemi proteases. Mol Microbiol 7, 141-150.

Watari, M., Tobe, T., Yoshikawa, M. \& Sasakawa, C. (1995). Disulfide oxidoreductase activity of Shigella flexneri is required for release of Ipa proteins and invasion of epithelial cells. Proc Natl Acad Sci USA 92, 4927-4931.

Wharam, S. D., Mulholland, V. \& Salmond, G. P. C. (1995). Conserved virulence factor regulation and secretion systems in bacterial pathogens of plants and animals. Eur J Plant Pathol 101, $1-13$.
Wolfe, A. J. \& Berg, H. C. (1989). Migration of bacteria in semisolid agar. Proc Natl Acad Sci USA 86, 6973-6977.

Wong, K. R. \& Buckley, J. T. (1991). Site-directed mutagenesis of a single tryptophan near the middle of the channel-forming toxin aerolysin inhibits its transfer across the outer membrane of Aeromonas salmonicida. J Biol Chem 266, 14451-14456.

Yamanaka, H., Kameyama, M., Baba, T., Fujii, Y. \& Okamoto, K. (1994). Maturation pathway of Escherichia coli heat-stable entertoxin I: requirement of DsbA for disulfide bond formation. J Bacteriol 176, 2906-2913.

Yanisch-Perron, C., Vieira, J. \& Messing, J. (1985). Improved M13 phage cloning vectors and host strains: nucleotide sequences of the M13mp18 and pUC19 vectors. Gene 33, 103-119.

Yu, J., Webb, H. \& Hirst, T. R. (1992). A homologue of the Escherichia coli DsbA protein involved in disulfide bond formation is required for enterotoxin biogenesis in Vibrio cholerae. Mol Microbiol 6, 1949-1958.

Yu, J., McLaughlin, S., Freedman, R. B. \& Hirst, T. R. (1993). Cloning and active site mutagenesis of Vibrio cholerae DsbA, a periplasmic enzyme that catalyses disulfide bond formation. J Biol Chem 268, 4326-4330.

Received 26 October 1998; revised 17 March 1999; accepted 12 April 1999. 